\title{
Escultores de oro y plata. En torno a la estimación del arte de la platería en España en el siglo XVI
}

\author{
Sculptors of gold and Silver. About the appreciation of the \\ art of silver work in 16th-century Spain
}

\author{
María Victoria HERRÁEZ ORTEGA \\ Insituto de Estudios Medievales (Universidad de León)
}

Recibido: 30-III-2016

Aceptado: 6-VI-2016

REsumen: La división establecida en el siglo XVIII entre artes mayores y artes menores aún se mantiene en gran parte de la historiografía artística y ha provocado una visión distorsionada de la realidad. Existe una conciencia generalizada de superioridad de unas artes frente a otras, que ya no se califican de menores pero que seguimos empeñados en meter en un mismo cajón de sastre para el que aún no hemos encontrado una etiqueta plenamente satisfactoria. Sin embargo, éste no era el criterio predominante en el siglo XVI, por lo que en este artículo tratamos de hacer memoria y de aproximarnos al conocimiento de la estimación del arte de la platería en la España de la decimosexta centuria, a través de un breve análisis de la valoración profesional del platero en tres niveles diferentes: el teórico, que es el de los tratados; el jurídico, que es el de la normativa legal y las ejecutorias ganadas en pleitos, y el del desarrollo cotidiano de su actividad.

Palabras clave: Arte de la Platería, España, Siglo XVI, Valoración de las Artes.

ABSTRACT: The division between major and minor arts, established in the 18th century, still remains in a great part of art historiography and has generated a distorted vision of reality. There is a generalised conscience of superiority of some arts above others, which are not called minor any more but that we are determined to put into the same muddle box for which we have not found a satisfactory label yet. Nevertheless, this was not the predominant criterion in the 16th century. That is why, in our paper, we try to remember and come closer to the knowledge of how the art of silver work was appreciated in 16th-century Spain, through a short analysis of how silversmiths were professionally valued on three different levels: the theoretical level, as shown in treatises; the juridical level, as shown in standard regulations and writs of execution gained in trials; and the level of the daily performance of their activity.

Keywords: The art of silver work, Spain, 16th century, Appreciation of the Arts. 
En abril de 1782 se comunicaba al Consejo y a la Real Academia de Bellas Artes de San Fernando una real orden para que fuera libre en todo el reino el ejercicio de las tres Nobles Artes: pintura, escultura y arquitectura1. Quedaba así definitivamente proclamada la liberalidad de unas artes que venían luchando por esa consideración desde hacía más de dos siglos. Pero si es cierto que los pintores batallaron por defender la liberalidad de la pintura, no lo es menos el empeño que pusieron en ello otros artífices y los éxitos que lograron en algunas ocasiones ${ }^{2}$.

La concepción artística jerarquizada en artes mayores y artes menores, nacida en el siglo XVIII, ha provocado una fractura en la historiografía artística que aún no hemos sido capaces de superar y que, en ocasiones, conduce a una visión distorsionada de la realidad de cada momento. A pesar de los cambios operados a partir del siglo XIX con los movimientos de Arts $\mathcal{E}$ Crafts y Art Nouveau, existe una conciencia generalizada de superioridad de unas artes frente a otras, que ya no se califican de menores pero que nos empeñamos en meter en un cajón de "otros" o

${ }^{1}$ La real orden fue comunicada a la Real Academia de Bellas Artes el 16 de abril de 1782 y está recogida en las Actas de la sesión celebrada el 5 de mayo siguiente (Actas de las sesiones particulares, ordinarias, generales, extraordinarias, públicas y solemnes de la Real Academia de Bellas Artes de San Fernando [manuscrito], fols. 205 y siguientes).

Este trabajo fue expuesto en el XVII Congreso Nacional del CEHA, celebrado en Barcelona en 2008. Se ha mantenido el texto de la subponencia prácticamente en su estado original, aunque se han añadido aquellas referencias que han sido publicadas en este tiempo intermedio y consideramos significativas para el tema. Quiero manifestar mi agradecimiento al Dr. Cruz Valdovinos por sus consejos y sugerencias.

${ }^{2}$ En los últimos años han hecho referencia a este tema M. C. HEREDIA, "La recepción del Clasicismo en la platería española del siglo XVI", en J. M. CASTILLO PASCUAL (coord.), Congreso Internacional "Imagines". La Antigüedad en las Artes escénicas y visuales, Logroño, 2008, pp. 445-478, especialmente 456-457, y J. M. CRUZ VALDOVINOS, "El fuero y el huevo. La liberalidad de la pintura: textos y pleitos", en J. RIELLO (ed.), Sacar de la sombra lumbre. La teoría de la pintura en el Siglo de Oro (1560-1724), Madrid, 2012, pp. 173-202. "varios" para el que es difícil encontrar una etiqueta válida (suntuarias, decorativas, industriales...). Sin duda, este estado de cosas es bien distinto del que prevalecía en el siglo XVI e, incluso, en el XVII.

En el caso de la platería, el famoso pleito que Juan de Arfe mantuvo en 1593 con los plateros burgaleses ha podido contribuir a la creencia de que se trataba de un arte menospreciado. Éstos pretendían que porta-ra el pendón de la cofradía de San Eloy en la procesión del Corpus y Arfe se negó aduciendo que no era cofrade ni vecino de esa ciudad. Las alegaciones se sucedieron $\mathrm{y}$, a lo largo del litigio, se pronunciaron frases ya famosas, como la del procurador del platero argumentando que no era platero "sino escultor de oro e plata e arquitecto" y la respuesta por parte del gremio burgalés de que "quererse llamar escultor de plata era nobedad porque escultor era propiamente el que labraba en madera o piedra, e platero se dezía el que labraba qualquiera cosa en oro o plata, aunque fuesen figuras e molduras e cosas semexantes e porque el oficio de escultor de plata qualquier buen platero lo era e devaxo del dicho nombre de platero se incluía, e porque llamarse plateros no era porque iciesen platos sino porque labraban en plata custodias, cruzes e otras figuras semexantes e mayores en toda perfección" ${ }^{\prime 3}$.

Juan de Arfe era un hombre del Renacimiento que tenía un alto concepto de sí mismo y sus palabras pueden interpretarse, en una primera lectura, como el deseo de apartarse de sus compañeros de oficio para equipararse a artífices más apreciados por su actividad, como los arquitectos o los escultores. Sin embargo, los plateros burgaleses, en un texto de aparente candidez, se muestran ajenos a una posible minusvaloración de su trabajo o de su persona.

${ }^{3}$ J. MARTÍ MONSÓ, "Pleitos de artistas. Juan de Arfe y el pendón de los plateros de Burgos", Boletín de la Sociedad Castellana de Excursiones, año V, 1907, no 57, pp. 189-196; J. M. CRUZ VALDOVINOS, “El platero Juan de Arfe", Iberjoya, no especial, 1983, pp. 3-22, especialmente 10-12. 
Como veremos más adelante, el pleito debe interpretarse en el contexto del funcionamiento del gremio burgalés y de las actividades profesionales y financieras desarrolladas por Juan de Arfe. Pero, ¿cuál era la situación real de la platería y de sus artífices en el siglo XVI.

En la Edad Media abundan los testimonios que permiten afirmar que los objetos suntuarios y sus artífices eran altamente apreciados $\mathrm{y}$, en ocasiones, más admirados que las obras y los maestros de la pintura o de la escultura. Unos y otros desempeñaban una labor en la que se valoraba esencialmente la habilidad técnica o el buen oficio; se consideraban menestrales y apenas hay indicios que permitan pensar que sintieron necesidad de que se valorara la componente intelectual de su trabajo. En el Quattrocento tomó carta de naturaleza la reflexión sobre la importancia de las premisas intelectuales que debían preceder a la ejecución manual. Fue a partir de ese momento cuando los artistas plásticos comenzaron a sentir la necesidad de incluir su actividad entre las artes liberales.

\section{LIBERALIDAD DEL ARTE DE LA PLA- TERÍA}

El asunto de la liberalidad de las artes no tenía una repercusión solo teórica sino que poseía connotaciones sociales, económicas y jurídicas. Sociales, por el estatus superior de las así consideradas; económicas, porque las artes liberales quedaban fuera del sistema impositivo, por ejemplo, para el pago de alcabalas o el repartimiento de soldados; y jurídicas, puesto que todo ello se refleja en la normativa vigente y dio lugar a un buen número de pleitos.

Vamos a hacer memoria y a tratar de aproximarnos al conocimiento de la estimación del arte de la platería en la España del siglo XVI, en tres niveles diferentes: el teórico, que es el de los tratados; el jurídico, que es el de las ejecutorias ganadas en pleitos y tiene una repercusión práctica en cuanto que determina los privilegios y exenciones de los que pueden o no gozar, y el del desarrollo cotidiano de la actividad, en el que se deben tener en cuenta factores como la formación, la organización del trabajo, la actitud de los clientes ante las obras, el nivel de vida, las relaciones sociales, el desempeño de cargos y toda una serie de parámetros que en el siglo XVI eran reflejo de consideración social.

La distinción entre artes liberales, que son las que sirven al hombre libre para encontrar la ciencia y el conocimiento, y las artes mecánicas y serviles, que sirven al hombre para ganar su sustento, proviene de la Antigüedad. Pero el término fue empleado, sobre todo, en la escolástica medieval para designar a las diferentes ramas del conocimiento que se enseñaban en las escuelas catedralicias, agrupadas en Trivium y Quadrivium. Decía Santo Tomás de Aquino que las artes liberales son más excelentes que las mecánicas, porque las artes mecánicas son prácticas y las liberales, especulativas ${ }^{4}$.

Fue en la Italia quattrocentista en donde comenzó a desarrollarse una conciencia profesional que buscaba el reconocimiento de la nobleza y la liberalidad de la pintura y la escultura, frente al ejercicio meramente manual de las actividades mecánicas y serviles, propias de los oficios menestrales.

Vasari contribuyó a ese nuevo concepto de artista con sus vidas de pin-tores, escultores y arquitectos. Junto a la ingenuidad o liberalidad, el tratadista italia-no quiso demostrar la nobleza de la pintura equiparando a sus artífices con los más encumbrados caballeros y zanjó la deba-tida cuestión de prioridad entre pintura y escultura concluyendo que son hermanas por ser ambas hijas del diseño ${ }^{5}$.

Leonardo da Vinci insistió en valorar el ejercicio de la pintura como cosa mentale,

${ }^{4}$ M. MENÉNDEZ PELAYO, Historia de las Ideas Estéticas en España, 5 vols., Madrid, 1883. Edición digital revisada por Enrique Sánchez Reyes a partir de la Edición nacional de las obras completas de Menéndez Pelayo, vol. I, Madrid, p. 171.

${ }^{5} \mathrm{G}$. VASARI, Le vite de' più eccellenti architetti, pittori et scultori italiani, da Cimabue insino á tempi nostri, Torino, 1991 (1556), p. 15. 
y no como un trabajo material, y la puso en relación con la poesía, retomando la célebre idea de Horacio en su Arte poética: "Ut pictura poesis...". La situó, incluso, por encima de otras Artes liberales, como la Música, y por delante de la Escultura, alegando que causa menos fatiga corporal.

Pero no vamos a detenernos en los tratados italianos que defienden la nobleza de la pintura y que sirvieron de acicate para que los artistas lucharan por una inde-pendencia laboral y una posición social destacada. Únicamente recordaremos, con Julián Gállego, que las razones teóricas en las que más se insiste para demostrarla son de carácter histórico, por el respeto que mereció a los antiguos; de carácter social, por el aprecio que le demuestran los grandes de este mundo; de carácter religioso, por la alusión a Dios como primer artista creador, a la práctica de la pintura por parte de san Lucas y a la función de vehículo que conduce el alma a la contemplación divina, y de carácter filosófico ${ }^{6}$.

La platería puede esgrimir argumentos similares: El más famoso y completo tratado sobre técnicas artísticas que se ha escrito en la Edad Media, De diversis artibus, obra del monje Teófilo, comienza el libro tercero, dedicado a los metales, con una declaración de principios según la cual las obras de platería se hacen para agradar a Dios, siguiendo una tradición que arranca del Antiguo Testamento ${ }^{7}$.

Efectivamente, en la Biblia se establece una comparación entre la palabra de Dios y la pureza de los metales nobles: "Palabras puras y sinceras son las palabras del Señor; son plata ensayada al fuego, acendrada en el crisol y oro siete veces refinado" ${ }^{\prime \prime}$. Pero el pasaje más significativo de la importancia concedida al arte de la platería y a sus ejecutores son

${ }^{6}$ Vid. J. GÁLLEGO, El pintor de artesano a artista, Granada, 1995 (1ª ed. 1976), pp. 31-51.

${ }^{7}$ Son muchas las ediciones que se han hecho del manuscrito. Para este estudio hemos utilizado la traducida y anotada por Hawthorne y Smith: THEOPHILUS, On Divers Arts, New York, 1979.

${ }^{8}$ Salmo 12,6 los versículos del Éxodo referidos a la construcción del Tabernáculo. Cuando el propio Yaveh encargó a Moisés la construcción del Arca de la Alianza, el propiciatorio, el candelero de siete brazos y los vasos y ornamentos para el Tabernáculo, especificaba que habían de estar recubiertos o labrados en oro puro y en plata y Él mismo designó a los orfebres que debían llevar a cabo tan delicado trabajo: Beseleel, al que había llenado "del espíritu de Dios, de saber y de inteligencia y de ciencia en toda suerte de labores, para inventar todo cuanto se puede hacer artificiosamente de oro y de plata, y de cobre...", y Ooliab9.

La estima que se tenía en la época bíblica a los metales, especialmente al oro, continuó en el mundo clásico y en la Edad Media. La consideración de las piezas de metal precioso como símbolo de la divinidad tuvo su punto álgido en los siglos medievales con los escritos del abad Suger (1081-1151), en los que se advierte un eco de las teorías de Pseudo Dionisio Areopagita (ca. 500). El convencimiento de que la contemplación del resplandor y la luz de los objetos materiales podría ayudar a los fieles a elevarse hacia el mundo de las virtudes celestiales, por medio de lo que denominó la "vía anagógica", explica los esfuerzos que llevó a cabo para aplicar en la abadía benedictina de Saint-Denis una nueva concepción arquitectónica en la que primara el concepto lumínico, para dotarla de una espléndida colección de objetos de culto y frontales de oro y piedras preciosas, así como para realzar la brillantez de las ceremonias litúrgicas. Más del ochenta por ciento del texto de Suger, Liber de rebus in administratione sua gestis (1144-1148), está dedicado al inventario de vasos sagrados, mobiliario y decoración del altar, el gran crucifijo de oro y la restauración de otros bienes del monasterio $^{10}$.

La posesión y exposición pública de objetos litúrgicos y ceremoniales de mate-riales nobles tuvo detractores, pero se mantuvo

\footnotetext{
${ }^{9}$ Éxodo 25, 10-30, y 31, 1-11.

${ }^{10}$ Entre las diversas ediciones y estudios dedicados a los escritos de Suger, uno de los más completos es el de F. GASPARRI, Suger. Oeuvres, Paris, 1996.
} 
como una constante debido a su carácter sagrado y de ofrenda divina. Así, a fines del s. XIII, Guillermo Durando justificaba la exposición de ornamentos en las fiestas principales por tres razones: "Primeramente, el poner de manifiesto la precaución y prudencia del que guarda aquello que le ha sido confiado. Segundo, por respeto a la solemnidad. Tercero, en memoria de su ofrenda, es decir, en recuerdo de aquéllos que las ofrecieron a la iglesia"11.

En este último punto, queda indirectamente enunciada otra función primordial de las piezas ricas: perpetuar la memoria del donante $\mathrm{y}$, en su caso, prestigiarle. Es decir, la platería religiosa además de cumplir una función litúrgica y devocional, es exponente del poder de quien la encarga, la dona o la utiliza. Ello hace que este tipo de obras se conviertan en un elemento común de las cortes medievales. Los nobles y, especialmente, la realeza, encargan a los plateros objetos de carácter cultual para sus capillas particulares o para las iglesias y monasterios tradicionalmente favorecidas por ellos (lámparas votivas, relicarios, cálices, frontales de altar $)^{12}$. Pero también requieren las insignias de su poder, objetos de adorno personal, vajilla y otros elementos que contribuyen al refinamiento y suntuosidad de sus residencias palaciegas y que les acompañaban en sus frecuentes desplazamientos.

Nos preguntamos, entonces, qué ocurrió en el paso de la Edad Media a la Edad Moder-

\footnotetext{
${ }^{11}$ Rationale Divinorum Officiorum (ca. 1286). Cfr. J. YARZA et alt., Arte Medieval II. Románico y gótico, col. "Fuentes y documentos para la Historia del Arte", vol. III, Barcelona, 1982, p. 229.

${ }^{12}$ En Cataluña, por ejemplo, la estabilidad alcanzada a partir del siglo XI y la consiguiente formación de las cortes condales y reales tuvo su repercusión en un aumento del esplendor del culto en las catedrales y monasterios. Fueron dotados con numerosos objetos que, al margen de su valor material y belleza formal, eran auténticos símbolos del sistema feudal debido a los lazos establecidos entre su función y motivación y el poder terrenal y la Iglesia. Vid. N. DALMASES y D. GIRALT-MIRACLE, Plateros y joyeros de Cataluña, Barcelona, 1985, pp. 9-11.
}

na y si en el siglo XVI ya se produjo una separación jerárquica entre el arte de los metales preciosos y las, posteriormente, denominadas Nobles Artes.En el ámbito del renacimiento italiano, la platería está íntimamente ligada a la escultura, tanto en el terreno de la práctica como en el de la teoría. Alberti, en su tratado De Statua diferencia tres tipos de maestros: los que trabajan sólo en desbastar, que son los escultores o tallistas; los que trabajan en poner y quitar, que son los modeladores, y los que trabajan sólo agregando material, que son los plateros. Por tanto, considera que los plateros están más cerca de los pintores, que agregan colores sobre la superficie de los cuadros, aunque producen un "artificio" distinto. En el Tratado de la Pintura se refiere al dibujo como señal de "ingenio excelente" y lo ejemplifica en la valoración de obras de platería en las que la hechura vale más que el material empleado ${ }^{13}$.

La Vita de Benvenuto Cellini, hijo de un hombre dedicado al arte liberal de la música, ilustra perfectamente cuál era la consideración del artista y cómo valoraban sus obras de metal precioso los grandes hombres, ya fueran papas, reyes o nobles. Si Cellini puede ser sospechoso de escasa objetividad cuando habla de sí mismo y de la admiración que causaba la calidad de su trabajo, de lo que no cabe ninguna duda es de la estrecha relación existente entre escultores y plateros. El propio Benvenuto escribió un tratado que dedica la primera parte a la orfebrería y la segunda a la escultura ${ }^{14}$. Brunelleschi se dedicaba a la escultura y la orfebrería, además de la arquitectura. Otros ejemplos que ilustran este maridaje son los de Donatello y Ghiberti, que se formaron en talleres de plateros florentinos; Giovanni di Baldassarre,

${ }^{13}$ Una primera aproximación al tema en D. NICOLÁS GÓMEZ, "La orfebrería en el tratado de la Pintura y en otros textos de Leone Battista Alberti", en J. RIVAS CARMONA (coord.), Estudios de platería. San Eloy 2003, Murcia, 2003, pp. 459-463.

${ }^{14}$ B. CELLINI, Due trattati vno intorno alle otto principali arti dell'oreficeria, l'altro in materia dell'arte della scultura, doue si veggono infiniti segreti nel lavorar le figure di marmo, [et] nel gettarle di Bronzo, Fiorenza, 1568. 
llamado el Piloto, practicaba ambas $\operatorname{artes}^{15}$; en Roma, el escultor Miche-langelo di Bernardino (1470-1540), al termi-nar la peste, hacia 1524, formó una compañía de pintores, escultores y plateros ${ }^{16}$. Además, a menudo los plateros eran también expertos medallistas, escultores y arquitectos. Es el caso de Alessandro Vittoria (1525-1608), colaborador de Jacopo Sansovino, que trabajó junto a Palladio y Veronés como maestro de los estucos de la villa Barbaro-Volpi en Maser ${ }^{17}$, o de Jacopo da Trezzo, platero italiano que llegó en 1584 a la corte de Felipe II, por recomendación de Pompeo Leoni, para encargarse del trabajo de arquitectura y de platería que requería el tabernáculo diseñado por Juan de Herrera para el retablo de la Basílica de El Escorial ${ }^{18}$, y dos años más tarde ya se denominaba "escultor de su magestad"19.

Los tratadistas españoles imitaron a los italianos, aunque el debate fue un poco más tardío y, probablemente, pesaron más los in-

${ }^{15}$ S. SANTERBÁS, Vida, anotaciones a la obra de B. Cellini, Vita, Madrid, 2007, 1. I, c. XXXII, p. 112.

${ }^{16}$ Ibídem, 1. I, c. XXX, p. 108.

${ }_{17}$ Orfebrería de los siglos XV y XVI, Barcelona, 1989, pp. 25-26. L. ATTARDI, "Alessandro Vittoria stucattore e l'ínfluenza di Michelangelo", en A. BACCHI, L. CAMERLENGO y M. LEITHE JASPER (eds.), "La Bellissima Maniera": Alessandro Vittoria e la Scultura Veneta del Cinquecento, Trento, 1999 , pp. 68-83.

${ }^{18}$ Pompeo Leoni comunicó al rey que lo complicado y minucioso del orden corintio aconsejaba la presencia del platero Jacopo da Trezzo. Afirma el Dr. Checa Cremades que, mientras Leoni se encargó de las esculturas, da Trezzo realizó la obra de arquitectura y platería. F. CHECA CREMADES, Felipe II. Mecenas de las artes, Madrid, 1992, p. 304.

${ }^{19}$ M. R. ZARCO DEL VALLE, Documentos de la catedral de Toledo, t. II, Madrid, 1916, pp. 238-239. En la catedral de Toledo se puede constatar la frecuente colaboración entre los plateros y otros artífices $\mathrm{y}$, especialmente, la estrecha relación existente entre escultores y plateros. Sirva de ejemplo el caso de Nicolás de Vergara el Viejo, arquitecto y escultor, que firmó conjuntamente con el platero Francisco Merino, en 1565, el concierto para la realización del Arca nueva de san Eugenio. Vid. M. PÉREZ GRANDE, "La platería", en La catedral primada de Toledo. Dieciocho siglos de historia, Burgos, 2010, pp. 362-381, especialmente 362-363. tereses de prestigio social y económico que los que afectan a la conciencia del propio artista como creador de obras de ingenio.

El primer alegato conocido hasta el momento en lengua castellana sobre la liberalidad de las artes y el libro más directamente dedicado a resolver esa cuestión es la Noticia general para la estimación de las artes, publicado por Gaspar Gutiérrez de los Ríos en 1600. No solo atiende a la pintura y la escultura, sino que incluye la platería, la tapicería y el bordado de matiz, actividades creativas, unidas por la necesidad de utilizar el dibujo y por su imitación de la naturaleza ${ }^{20}$. Dice el autor que "por la gente vulgar e idiota, sin ingenio y conocimiento de virtud, se menosprecia estas Artes, de la manera que las perlas y piedras preciosas por los puercos..."21.

Pero ya antes de esta publicación, cuyo origen está en la defensa de los artífices en un pleito suscitado en Madrid en 1597, sobre el que volveremos más adelante, la tratadística hispana hace referencia al asunto. Diego de Sagredo pone en boca de Tampeso la diferenciación entre los oficiales mecánicos y los liberales y establece una clara prelación de la pintura y la escultura sobre otras actividades artísticas y, en concreto, sobre la platería.

${ }^{20}$ El interés por algunas de estas actividades debía estar incentivado por su padre, Pedro Gutiérrez, tapicero al servicio de Felipe II. M. T. CRUZ YÁBAR, La tapicería en Madrid (1570-1640), Madrid, 1996, pp. 24 y siguientes.

${ }^{21}$ G. GUTIÉRREZ DE LOS RÍOS, Noticia General para la Estimación de las Artes y de la manera en que se conocen las liberales de las que son Mecánicas y serviles, con una exhortación a la honra de la virtud y del trabajo contra los ociosos, y otras particulares para las personas de todos los estados, Madrid, 1600, Lib. III, cap. XVIII, p. 212. Transcrito en J. M. CERVELLÓ GRANDE, Gaspar Gutiérrez de los Ríos y su Noticia General para la Estimación de las Artes, Madrid, 2006, vol. I, pp. 105-233. Antes de la edición del libro de Gutiérrez de los Ríos por parte de José María Cervelló, ya había abordado el estudio de su vida y obra M. T. CRUZ YÁBAR, “Gaspar Gutiérrez de los Ríos, teórico de la estimación de las artes. Biografía", Academia. Boletín de la Real Academia de Bellas Artes de San Fernando, no 82, 1996, pp. 401-460, y “Gaspar Gutiérrez de los Ríos, teórico de la estimación de las artes. II. Formación y obra", Academia. Boletín de la Real Academia de Bellas Artes de San Fernando, no 84, 1997, pp. 383-422. 
Dice de los primeros que son los que "trabajan con el ingenio y con las manos, como los canteros, plateros, carpenteros, cerrageros, campaneros y otros oficiales que sus artes requieren mucho saber e ingenio. Pero liberales se llaman los que trabajan solamente con el espíritu y con el ingenio, como son los gramáticos, lógicos, retóricos, arisméticos, músicos, geométricos, astrólogos, con los cuales son numerados los pintores y esculptores, cuyas artes son tan estimadas por los antiguos que aún no son por ellos acabadas de loar, diziendo que no puede ser arte más noble ni de mayor prerrogativa que la pintura que nos pone ante los ojos las historias y hazañas de los passados..."22.

Felipe de Guevara, al final de sus Comentarios de la pintura, anota una frase que, con ser la única en todo el texto que afecta a la demostración teórica de la nobleza de este arte, es la más idealista definición de la pintura que se puede encontrar en un libro castellano del siglo XVI: "pintar es demostrar las ideas con las manos" ${ }^{\prime 23}$. Pero eso no significa que los pintores hayan obtenido el reconocimiento al que aspiraban ni su actividad se considere liberal. Francisco de Villalpando hace apología de su oficio de arquitecto -una de sus ocupaciones, porque como rejero mostró su maestría en las rejas de la capilla mayor y del coro de la catedral de Toledo- y de los de pintor y escultor, al tiempo que se queja de la poca estima en la que se tiene a los que practican estas artes, pues dice que "son tan mal premiados de los que lo avían de ser, que tienen por mejor ser tenidos por hombres baldíos que tener nombre de artistas. Y no es de maravillar, porque considerando en quan poco son tenidos los que en las tales artes se emplean, si no fuesse por ser algunos constreñidos de necessidad en ellas no se ocuparían especialmente viendo que delante de un príncipe $u$ otro señor es en más tenido uno que no tenga nom-

${ }^{22}$ D. de SAGREDO, Medidas del romano, Toledo, 1526, fol. 7v. (ed. facsimilar Valencia, 1976).

${ }^{23}$ F. de GUEVARA, Comentarios de la pintura, Madrid, 1788 (Cfr. J. GÁLLEGO, Op. cit., p. 59). bre de artista, aunque sea baxo e de ningún fructo, que otro que lo sea y tenga sin el arte otras partes mejores" ${ }^{24}$. Es decir, que a mediados del siglo XVI, a pesar de los esfuerzos de los teóricos, ni el arte de la pintura ni el de la escultura habían alcanzado la estima que sus artistas deseaban; se consideraba, incluso, que envilecían a quien las practicara. Otra prueba de ello es la "Regla y establecimientos nuevos de la Orden de Santiago", redactada en 1563, que inhabilitaba para entrar en la Orden como caballeros a aquéllos que practicaban oficios viles y mecánicos y citaba expresamente: "platero o pintor que lo tengan por oficio", equiparando ambas actividades $^{25}$.

En lo que se refiere a la platería, amén de las referencias anteriores, que la sitúan una de ellas (Sagredo) por debajo de la pintura y la otra (Regla de la Orden de Santiago) en una posición equiparable, como oficios ambos serviles, dos de los tratados más importantes y con más repercusión en la literatura artística posterior le dedican especial atención y señalan explícitamente su liberalidad y nobleza. Uno de ellos es el ya aludido de Gaspar Gutiérrez de los Ríos, que defendió a los plateros junto a los pintores, escultores, tapiceros y bordadores en el pleito de 1597 contra el concejo de Madrid, que les reclamaba la contribución para la leva de soldados. En él justifica la liberalidad de la platería, fundamentalmente, por el uso que requiere del dibujo y explica que no llama artífices plateros "a todos los que tratan el ministerio de la plata y oro, sino solo a aquéllos que dibujan, esculpen y relievan, en pequeño o en grande, figuras e historias al vivo, de la manera que se hace por artífices escultores" ${ }^{\prime 26}$.

El otro tratado dedicado a la platería, aun cuando su título no lo haga explícito, es

${ }^{24}$ F. de VILLALPANDO, Sebastián Serlio. Tercero y quarto libro de architectura, Toledo, 1552, fol. 2v. (ed. facsimilar Valencia, 1977).

${ }^{25}$ Cfr. F. MARÍAS, El largo siglo XVI: los usos artísticos del Renacimiento español, Madrid, 1989, p. 473.

${ }^{26}$ G. GUTIÉRREZ DE LOS RÍOS, Op. cit., lib. III, cap. III, p. 128. 
la Varia conmensvración para la Esculptura y la Architectura (1587), primer tratado de escultura escrito en España, uno de los primeros editados de arquitectura y el segundo de platería, después del Quilatador de oro, plata y piedras (1572), obra también de Juan de Arfe, pero dedicada exclusivamente a tratar aspectos técnicos del trabajo de los metales preciosos. En el prólogo de la Varia conmensvración, Arfe hace una declaración de principios en la que defiende la platería como arte liberal que requiere de los conocimientos de la arquitectura y de la escultura. Justifica esa necesidad aludiendo a que los principales escultores y arquitectos de la Antigüedad fueron maestros en labrar los metales, y no solamente en la realización de figuras sino también en la fabricación de vasos y otras piezas que ahora labran los plateros; dice que antiguamente no había diferencia entre los escultores y arquitectos y los que ahora se llaman plateros y, así, los preceptos de los unos son necesarios para los otros. Insiste, también, en la necesidad que tienen de conocer aritmética, geometría, astrología, dibujo, anatomía, arquitectura, perspectiva y pintura, por lo que es fundamentalmente a ellos a quienes espera que aproveche y sea útil su libro. Por tanto, Juan de Arfe, a diferencia de Gutiérrez de los Ríos, defiende la ingenuidad de la platería no solo en su faceta más próxima a la escultura, es decir, la creación de figuras y relieves, sino también en la elaboración de piezas propias de los plateros ${ }^{27}$.

\section{PRIVILEGIOS Y EXENCIONES DE LOS PLATEROS}

El siglo XVI es la Edad de Oro de la platería española. Durante este tiempo los plateros hispanos lucharon por la consideración de su actividad como un arte liberal frente a las denominadas artes mecánicas. En esa batalla, en la que había sido pionera la pintura italiana, se hizo especial hincapié en las ventajas prácticas que la nobleza del arte llevaba

${ }^{27} \mathrm{~J}$. de ARPHE Y VILLAFAÑE, De varia commensvracion para la Esculptura y Architectura, Sevilla, 1587 (ed. facsímilar Valencia, 1979), s/f. consigo, especialmente la exención del pago de impuestos o alcabalas por la venta de las obras. Lo cierto es que los plateros fueron los primeros en conseguir dicha exención, diferenciando la creación artística de un contrato de compraventa (do ut facias en lugar de do ut das), uno de los argumentos que serían más utilizados en la defensa de la liberalidad de la pintura en el siglo XVII ${ }^{28}$. Precisamente, Juan de Butrón se refirió a la posición de la platería cuando afirmó que los pintores españoles podían ser tan libres de pagar alcabala como los plateros quienes, de acuerdo a las leyes promulgadas por Fernando e Isabel, pagaban impuestos solo sobre sus materiales y no por su trabajo ${ }^{29}$.

En efecto, los Reyes Católicos, al legislar sobre las alcabalas dispusieron que se aplicasen a toda clase de compraventa de bienes muebles, inmuebles y semovientes en una cuantía del 10\%. Los plateros figuraban exentos por el oficio, siempre que trabajaran con material ajeno; si labraban el propio, tenían que pagar sólo sobre el valor del material $^{30}$.

Esta consideración del trabajo del platero, no como contrato de compraventa sino del tipo do ut facias, fue alegada en el siglo XVII por los pintores, que pretendían la misma exención. Felipe II lo ratificó al extender

${ }^{28}$ Las alcabalas habían sido establecidas por Alfonso XI en 1342 para la guerra contra los moros y la conquista de Algeciras. J. M. CRUZ VALDOVINOS, “El fuero y el huevo...", hace referencia a los pleitos sostenidos por los plateros en el siglo XVI como precedente de las reivindicaciones de los pintores.

${ }^{29}$ J. A. de BUTRÓN, Discursos apologéticos en que se defiende la ingenuidad del arte de la pintura: que es liberal, de todos derechos, no inferior a los siete que comunmente se reciben, Madrid, 1626. P. MULLER, “Spain's Golden Age in Silver", Apollo, 122, 1972, pp. 264-271.

${ }^{30}$ Pragmática de 1491, recogida en el llamado Cuaderno Nuevo. Novísima Recopilación de las leyes de España dividida en XII libros en que se reforma la Recopilación publicada por el señor Don Felipe II en el año 1567, reimpresa ultimamente en el de 1775; y se incorporan las pragmáticas, cedulas, decretos, órdenes y resoluciones reales y otras providencias no recopiladas y expedidas hasta el de 1804. Mandada formar por el señor Carlos IV, Madrid [s.n.], 1805-1807, lib. IX, tit. 17, ley 9. 
a los plateros americanos el privilegio del que gozaban los castellanos disponiendo: "Que no paguen alcabala por la labor y sí del oro que labraren o hicieren labrar para vender"31.

La exención de alcabalas por la actividad fue un reconocimiento temprano de la liberalidad del trabajo de los plateros ${ }^{32}$. Sin embargo, en otros campos aún tendrían que defender su superioridad profesional respecto a los oficios mecánicos.

Una de las circunstancias que más documentación ha generado a ese respecto es la prohibición de llevar seda en los vestidos, impuesta a los oficiales y sus mujeres por una pragmática de las Cortes reunidas en Valladolid en 1523. Al año siguiente, los plateros de Toledo, por carta ejecutoria de Carlos I y la reina Juana, consiguieron que se suspendiese el capítulo respecto a ellos y se les devolviesen las ropas que los alguaciles les habían quitado ${ }^{33}$. Pero mayor repercusión tuvo el pleito que ganaron los placentinos en su alegación contra la pragmática de 1551, que reiteraba la prohibición ${ }^{34}$. La sentencia reconocía que "no se proybía a los

${ }^{31}$ Ibídem, lib. VIII, tit. 13, ley 9.

${ }^{32}$ J. M. CRUZ VALDOVINOS, "El fuero y el huevo...", especialmente pp. 200-202, concluye que el reconocimiento de exención del pago de alcabalas, tanto en el caso de los plateros como en el de los pintores, no se debió a la consideración de la ingenuidad de tales Artes, aunque se esgrimiera en todos los casos ese argumento.

${ }^{3}$ ÍDEM, Los plateros madrileños. Estudio histórico-jurídico de su organización corporativa, Madrid, 1983, p. 229.

${ }^{34}$ G. GUTIÉRREZ DE LOS RÍOS, Op. cit., p. 206, y J. GÁlleGO, Op. cit., p. 70, apuntan Palencia. J. M. CRUZ VALDOVINOS, Los plateros madrileños..., p. 229, y M. PÉREZ HERNÁNDEZ, “La cofradía de San Eloy", en AA.VV., La platería en la época de los Austrias Mayores en Castilla y León, Valladolid, 1999, p. 68, según consta en el Archivo del Gremio de Salamanca, aclaran que se trata de Plasencia.

"Item mandamos que los oficiales menestrales de manos, sastres, zapateros, carpinteros, herreros, texedores, pellejeros, tundidores, curtidores, zurradores, esparteros y especieros, y de otros cualquier oficio semejantes a estos más bajos y obreros y labradores y jornaleros no puedan traer ni trayan seda alguna..." (Novísima Recopilación..., lib. VI, tit. XIII, ley I.15). artifizes y plateros el traer de la seda porque su Arte no hera ofizio y ansi los Derechos les nombraban artifizes y no oficiales" ${ }^{\prime 35}$. Es interesante la alusión a que en el derecho estaba consagrado el término artífice para el platero y, sobre todo, el reconocimiento de su diferenciación profesional respecto a los oficiales.

Así, los plateros y sus mujeres, al contrario que los practicantes de oficios mecánicos, ya no estaban afectados por la prohibición de vestir sedas ${ }^{36}$, pero lo más importante fue el precedente que esta exención sentó a la hora de dirimir otras causas en defensa de la liberalidad de la platería.

Otro de los asuntos que indujo a los plateros a reivindicar la condición de arte para su actividad fue la supresión de las cofradías particulares de oficios, dictada por pragmática de Carlos I en 1552, y la orden de que fueran los regimientos quienes nombrasen los veedores para juzgar la producción que salía al mercado ${ }^{37}$. El intento por parte de los

${ }^{35}$ Nueva Recopilación, Madrid, 1567, lib. VII, tit. 12, ley 2. Cfr. J. M. CRUZ VALDOVINOS, Los plateros madrileños..., p. 229.

${ }^{36} \mathrm{El}$ reconocimiento de ese privilegio se extendió a otros centros plateros (vid. C. GARCÍA GAÍNZA, La platería de Pamplona, Pamplona, 1991, p. 14). No obstante, las sentencias favorables no tuvieron un carácter perpetuo, sino que, cada cierto tiempo, se planteaba de nuevo el asunto. En 1691, el Consejo aclaraba "no comprehenderse en esta pagmática de trages los maestros de obras, plateros, pintores, mercaderes de libros y cirujanos que no fuesen barberos ni tuviesen tienda de tales" (Novísima Recopilación..., lib. VI, tit. XIII, ley I).

${ }^{37}$ Fue la respuesta a la petición realizada por las Cortes de Madrid.

"Otro si mandamos que las cofradías que ay en estos reynos de oficiales se deshagan y no las aya de aquí adelante aunque esten por nos confirmadas y que a titulo de los tales oficios no se puedan juntar ni hazer cabildo ni ayuntamiento so pena de cada diez mil maravedis (sic) y destierro de un año del reyno. Y porque conviene que los dichos officiales usen bien de sus officios y en ellos aya veedores, mandamos que la justicia y regidores de cada ciudad, villa o lugar vean las ordenanzas que para el uso y exercicio de los tales officios tuvieren y platiquen con personas expertas y hagan las que fueren necessarias para el uso de los dichos officios... y que cada año la justicia y regidores nombren veedores 
poderes municipales de llevar a la práctica esta legislación provocó en los años siguientes la reacción de diversas cofradías de plateros, que consiguieron eludir la referida ley con la alegación de que no eran oficiales sino artífices, según había sido admitido en el pleito de los plateros placentinos antes mencionado ${ }^{38}$. El argumento quedó confirmado por varias reales ejecutorias que consagraron en adelante la condición de artistas para los plateros. Aunque no resultó válido para todos ni para siempre, fue el caso de la hermandad sevillana de San Eloy que, además de reivindicar la condición de artistas para sus miembros, mantuvo, entre 1554 y 1566, un pleito contra los marcadores que pretendían nombrar los reyes. Su intención primordial era continuar su existencia como corporación y mantener sus derechos en lo relativo al marcaje de la plata, es decir, que los pesos, pesas y marcas continuasen en poder de sus veedores. A lo largo del pleito, se hace alusión a la preeminencia de la corporación de los plateros sobre otros gremios, especialmente cuando se defiende que es un arte noble porque necesita ciertas artes liberales, como la geometría y la perspectiva $^{39}$.

abiles y de confianza para los dichos officios y que la justicia execute las penas en ella contenidas" (Biblioteca de Santa Cruz de Valladolid, Reales Ordenanzas y Pragmáticas (1527-1567), ms. 12437 (ed. facsimilar Valladolid, 1987), s/fol.

${ }^{38}$ A. BARRÓN GARCÍA, La época dorada de la platería burgalesa. 1400-1600, Salamanca, 1998, t. I, p. 70.

${ }^{39}$ La real ejecutoria que sentenció el juicio entre los plateros de Sevilla y el delegado del marcador mayor dice que "la premática hecha en el año de quinientos e cinquenta e dos en la Villa de Madrid, que en efecto manda que se deshagan las cofradías de oficiales, esta premática no se puede ni debe de estender a los artistas plateros ni habla de ellos, porque la premática que habla de oficial no se debe ni a de estender al aurífice ni artista como son los plateros e porque el oficial es cosa muy distinta e apartada del artista, porque el oficial es que hace obra cuya compusición no se requiere ciencia ni arte liberal, e artífice se dize a aquel cuya obra no se puede hazer sin ciencia y alguna de las siete artes liberales". Vid. M. J. SANZ SERRANO, El gremio de plateros sevillano. 1344-1867, Sevilla, 1991, pp. 39-47 y 196-223, especialmente 200, y Una hermandad gremial: San Eloy de los plateros (1341-1914), Sevilla, 1996, p. 92.
Pleitos similares, y con los mismos argumentos, ganaron los plateros por otras causas, como el repartimiento para costear las danzas del Corpus. En 1578, parece que se dictó una provisión real a favor de los plateros de Toledo en la que se ordenaba que no se les repartiesen maravedís contra su voluntad para la fiesta del Corpus ${ }^{40}$. A pesar de ello, en 1580, la cofradía de San Eloy de dicha ciudad hubo de ganar la apelación ante el Consejo Real contra un auto y sentencia dictados por el corregidor, por el que les condenaba a pagar dos ducados para ayuda de una danza del Corpus Christi que habían de sufragar varios gremios. Alegaron que eran "officiales de Arte, que era cossa muy distinta de los officios de las partes contrarias" ${ }^{41}$. El Consejo anuló el auto del corregidor y la Platería consiguió, como Arte, la exención de costear las danzas que habían sido sufragadas, hasta entonces, por nueve oficios. Aún en 1582, Felipe II daba una carta ejecutoria en la que declaraba a los plateros de Toledo exentos de contribuir a las danzas de dicha festividad $^{42}$.

Tampoco consideraban los plateros que tuvieran obligación de participar en el mantenimiento de soldados. Este asunto generó, en 1597, el pleito contra el concejo de Madrid, cuya alegación fue redactada por el abogado Gaspar Gutiérrez de los Ríos, que, como ya he comentado, asumió la defensa común de pintores, escultores, plateros, tapiceros y bordadores. El corregidor de la Villa había solicitado a las cofradías la lista de los individuos adscritos a ellas para el reclutamiento de soldados $\mathrm{y}$, al negarse los mayordomos de San Eloy a dar cuenta de ello, ordenó su encarcelamiento. Los artífices plateros habían

\footnotetext{
${ }^{40}$ M. PÉREZ HERNÁNDEZ, Op. cit., p. 68, aunque no cita fuente. J. M. CRUZ VALDOVINOS, “El fuero y el huevo..." p. 175, dice que, al parecer, habían conseguido una ejecutoria a su favor el 14 de agosto de 1578 , pero al año siguiente fueron denunciados por los tundidores.

${ }^{41}$ J. M. CRUZ VALDOVINOS, Los plateros madrileños..., p. 229.

42 ÍDEM, “El fuero y el huevo...”, p. 175.
} 
contestado que "por ser Arte el oficio de plateros no estaban obligados a dar soldados ni que se les repartiese cosa alguna"43.

El sentimiento de superioridad de los plateros respecto a los oficios manuales debió acentuarse progresivamente. En algunos contratos burgaleses de la segunda mitad del siglo XVI se advierten enmiendas realizadas con el fin de sustituir el término oficio por el de arte, seguramente a petición del platero $^{44}$. En la Regla de la Cofradía de Madrid, redactada en 1575, se utilizaba el término oficio para designar el ejercicio de la platería; en las Ordenanzas de 1637 se sustituyó cuidadosamente por el de Arte, incluso en aquellos párrafos que reproducían literalmente el texto de $1575^{45}$.

El desenlace de todos los pleitos citados fue satisfactorio para la Platería y rentable desde el punto de vista económico, pero no definitivo para su consideración pues, a lo largo del siglo XVII, siguen sucediéndose las reclamaciones que insisten en la naturaleza liberal de la actividad como justificación para no contribuir con los gremios. Además, los conflictos sobre la ingenuidad del ejercicio de la platería debieron ser frecuentes y la equiparación a otros oficios manuales parece un argumento habitual de sus detractores ${ }^{46}$.

\section{CONSIDERACIÓN SOCIAL}

Para conocer el estatus social de los plateros y la consideración de su trabajo en

${ }^{43}$ ÍDEM, Los plateros madrileños..., p. 229.

${ }^{44}$ A. BARRÓN GARCÍA, “Juan de Arfe en Burgos", Burgense, 35/1, 1994, pp. 249-278, especialmente 274.

${ }^{45}$ J. M. CRUZ VALDOVINOS, Los plateros madrileños..., p. 230.

${ }^{46}$ Las circunstancias no difieren de las de otras artes, como es el caso de la pintura. Véanse, al respecto, E. LAFUENTE FERRARI, "Borrascas de la pintura y triunfo de su excelencia", Archivo Español de Arte, XVII, 1944, pp. 90-103; M. P. MORENO PUERTOLLANO, “Los pintores madrileños y la cofradía de Nuestra Señora de los Siete Dolores", Anales del Instituto de Estudios Madrileños, nº 23, 1986, pp. 51-58; J. M. CRUZ VALDOVINOS, "El fuero y el huevo..." la vida cotidiana, habría que analizar diferentes parámetros y compararlos con los de otros grupos artísticos ${ }^{47}$. No se pueden obtener conclusiones válidas sin un estudio estadísticamente significativo que permita valorar los diferentes casos dentro del conjunto general y en comparación con otros colectivos, lo que sobrepasa ampliamente la intención de este texto. Únicamente, vamos a hacer un recorrido por diferentes aspectos que deberían tenerse en cuenta y a ilustrarlos con algún ejemplo, sin la pretensión de ser exhaustivos ni establecer doctrina al respecto, sino sólo como forma de aproximarnos a una realidad social de la que aún nos falta mucho por conocer.

El contacto con los metales preciosos y la capacidad de control sobre ellos, así como la categoría de los clientes y la elaboración de sellos, medallas y otros objetos de representación, otorgaban a los plateros un prestigio y un peso social que no poseían otros grupos profesionales. Tal vez por eso

\footnotetext{
${ }^{47}$ La bibliografía sobre la condición social del artista se refiere en su mayor parte sólo a los pintores o a los arquitectos, pintores y escultores en general, dejando al margen otras artes o aludiendo a alguno de sus artífices de forma tangencial. Son títulos señalados: E. LAFUENTE FERRARI, Op. cit.; J. J. MARTÍN GONZÁLEZ, "La vida de los artistas en Castilla la Vieja y León durante el Siglo de Oro", Revista de Archivos Bibliotecas y Museos, 1959, pp. 391-439, y El artista en la sociedad española del siglo XVII, Madrid, 1984; J. GÁLLEGO, Op.cit.; F. CHECA CREMADES, Pintura y escultura del Renacimiento en España, Madrid, 1983; F. MARÍAS, Op.cit., 1989, pp. 453-517. Por lo que respecta a la condición del platero, cabe señalar las referencias que dan F. PACHECO, El arte de la pintura, Madrid, 1990 (1 $1^{\underline{a}}$ ed. Sevilla, 1649), p. 554; y A. PALOMINO, El museo pictórico y escala óptica, Madrid, 1947 (1ª ed. Madrid, 1715), vol. I, pp. 257-258. Los estudios regionales de platería cada vez son más numerosos y prestan mayor atención a los aspectos sociales en los que se desarrolla la vida de los plateros, por lo que únicamente voy a destacar algunos como J. M. CRUZ VALDOVINOS, Los plateros madrileños...; M. C. HEREDIA MORENO, "Consideración social del platero en el siglo $\mathrm{XVI}^{\prime}$, Historia Abierta, $\mathrm{n}$ - 30, 2002, pp. 21-24; M. C. PESCADOR DEL HOYO, "Los gremios de artesanos en Zamora”, Revista de Archivos Bibliotecas y Museos, t. LXXVIII, 1, 1975, pp. 111-188; M. J. SANZ SERRANO, El gremio de plateros sevillano. 1344-1867, Sevilla, 1991; M. PÉREZ HERNÁNDEZ, Op. cit., pp. 57-71.
} 
se preocupó el Ayuntamiento de Burgos cuando algunos plateros, siguiendo el curso de la población que se desplazaba hacia los barrios bajos, comenzaron a aproximar su residencia y sus tiendas a la Llana. En 1536 la Chancillería confirmaba una provisión de los Reyes Católicos sobre la obligatoriedad de que los plateros vivieran en el barrio alto y se mantuvieran juntos en la calle Tenebregosa, una de las más animadas de esta zona en la primera mitad del siglo XVI. El texto decía que el oficio era de tal calidad que obligatoriamente el público tendría que acudir allá donde estuviesen. Recordaba que la platería era "el prinçipal oficio para el hornato de dicha calle" y que "a causa de darles el dicho sitio se despobló la calle de la platería vieja en la que antes solian vebir [la calle de las Armas]" ${ }^{\prime 4}$.

Si en este caso el peso específico que tenían en la ciudad obró en contra de sus intereses de libre establecimiento, en otros les reportó algún privilegio, como les ocurrió a los plateros de la calle Costanilla de Valladolid, que fueron eximidos de alojar en sus casas a personas de la comitiva real debido a que tenían mucha riqueza en metales y piedras preciosas y la mayor parte de él pertenecía a gente noble ${ }^{49}$.

\section{LA CORPORACIÓN}

Las corporaciones de plateros alcan-zaron una gran fuerza en algunas ciudades europeas desde fechas muy tempranas. Sirva de ejemplo el caso de Londres, cuya Compañía de plateros era, en 1180, el más poderoso de los dieciocho gremios que fueron multados por la Corona por haberse constituido como asociaciones sin contar con la debida autorización; en 1368, estaba formada por 135 miembros y en 1465, cuando León de

\footnotetext{
${ }^{49}$ Privilegio concedido por Juan II en 1440 y confirmado por los Reyes Católicos, Carlos I y Felipe II. Es en la ratificación de 1527 en la que se da esta explicación. M. PÉREZ HERNÁNDEZ, Op.cit., pp. 57-71.
} 66

${ }^{48}$ A. BARRÓN GARCÍA, La época dorada..., t. I, p.
Rosmithal visitó la ciudad, la integraban ya 400 maestros, sin contar los oficiales.

En la Península Ibérica, la mayoría de los que hoy llamamos artistas no tuvieron gremio propio hasta finales de la Edad Media. Los plateros, como otros muchos artesanos, sintieron la necesidad de asociarse con fines de protección y control, pero, a diferencia de otros oficios, desde muy temprano constituyeron corporaciones independientes y con un carácter prácticamente exclusivo, a pesar de no rechazar explícitamente, en principio, a los que practicasen otra profesión.

No existe uniformidad en cuanto a la fecha, denominación (cofradía, hermandad o gremio) y ordenanzas de las corporaciones surgidas en las diferentes ciudades españo-las. A la cofradía, en principio, le competen los asuntos religiosos y aquéllos relacionados con la beneficencia; al gremio, los aspectos profesionales: garantía de calidad del trabajo realizado, formación de los profesio-nales, control de la competencia,... Las agrupaciones más antiguas aparecen con el nombre de cofradías, con el que era más sencillo obtener el permiso de asociación, y, realmente, en sus Reglas sólo figuran la asistencia social a los miembros y la celebración de la festividad del santo Patrón, san Eloy. Sin embargo, en la mayoría de los casos, debido a la especialización de oficio de los congregantes, pronto comenzaron a regularse asuntos laborales, por lo que se ha hablado de cofradías de oficios o cofradías gremiales ${ }^{50}$.

La corporación de plateros más antigua es la de Valencia, cuya regla fue confirmada en 1298 por Jaime II, aunque luego sufriera una supresión transitoria ${ }^{51}$; en Sevilla, la

${ }^{50}$ Así se denominan los azabacheros de Santiago de Compostela en sus ordenanzas de 1443 (A. LÓPEZ FERREIRO, Fueros municipales de Santiago y su tierra, Madrid, 1971, pp. 491 y siguientes).

${ }^{51}$ A. IGUAL ÚBEDA, El gremio de plateros (Ensayo de una historia de la platería valenciana), Valencia, 1956, p. 71; F. COTS MORATÓ, “Un real privilegio de Alfonso V para los plateros de la ciudad de Valencia", Saitabi, $\mathrm{n}^{\mathrm{o}}$ 46, 1996, pp. 347-357. 
Hermandad de San Eloy gozaba de regla en 1341, mientras que las primeras noticias sobre el gremio llevan a situar su inicio en 134452; en Barcelona se dictaron las primeras Reglas en 1381 y las ordenanzas gremiales más antiguas datan de $1402^{53}$; la cofradía salmantina se instituyó en 1450 y la vallisoletana, en $1452^{54}$.

Existe un paralelismo con otras profesiones artesanales en el sentido de que no se tienen en cuenta aspectos intelectuales, de reflexión sobre el sentido del oficio. Sin embargo, es excepcional el hecho de que los plateros aparezcan desde sus orígenes con carácter especializado, pues lo habitual fue que se agruparan oficiales y artífices de distintas profesiones en una misma cofradía, ya que las finalidades declaradas en la asociación no tenían carácter profesional. Así, por ejemplo, los azulejeros valencianos se unieron en 1483 al gremio de albañiles; en 1498 se separaron y 2 años más tarde ya se hicieron ordenanzas con normas específicas para ellos $^{55}$. En Mallorca, los pintores constituyeron una cofradía o colegio en 1486, pero en 1511 solicitaron instituir una asociación con los bordadores y fundaron el Collegi de Brodadors y Pintors, o Confraría de nostra Dona de la Clastra. Más tarde ingresaron también en ella los escultores, convirtiéndose en la Confratría brodaderiorum, pictorum et imagina-

52 J. M. CRUZ VALDOVINOS y B. SANTA-MARINA NOVILLO, "Notas sobre la más antigua normativa profesional de los plateros sevillanos", en Actas del I Congreso de Historia de Andalucía. Andalucía moderna (siglos XVI-XVII), t. I, Córdoba, 1978, pp. 321-329, ya databan esa primera normativa en época de Alfonso XI; $M$. J. SANZ SERRANO, Una hermandad gremial..., da las fechas concretas.

${ }^{53}$ De 1381 data el privilegio del infante Juan en el que reconoce los estatutos y otorga el derecho de nombrar sus mayordomos en la festividad de San Eloy. N. de DALMASES I BALAÑÁ, Orfebreria catalana medieval. Barcelona 1300-1500: aproximació a l'estudi, Barcelona, 1992, t. I, pp. 47-48.

${ }^{54}$ M. PÉREZ HERNÁNDEZ, La congregación de plateros de Salamanca, Salamanca, 1990, p. 28, doc. 1 del apéndice documental.

${ }^{55}$ J. YARZA et alt., Op. cit., doc. 99, pp. 278-283. riorum. Los pintores no se independizaron hasta $1602^{56}$.

La intromisión de las cofradías en la regulación de distintos aspectos de la vida laboral motivó el descontento de las autoridades, tanto municipales como del reino, a las que competía la legislación sobre dichas cuestiones. Ya las Partidas de Alfonso X habían tratado de limitar la función de estas asociaciones a fines religiosos y benéficos y las Cortes de 1371, ante las quejas que provocaban los acuerdos corporativos, pidieron a Pedro I que las disolviera y prohibiera a los oficios formar cofradías particulares.

El problema se agravó en la medida en que tales cofradías gremiales tendieron a la especialización de oficios y comenzaron a ejercer un verdadero control sobre la producción. En el siglo XVI se produjo un distanciamiento entre las cofradías religiosas y las cofradías de oficios, recon-vertidas en gremios, que alcanzaron en esta centuria su verdadero desarrollo. Fue entonces cuando se establecieron nuevas disposiciones legales que trataban de limitar su capacidad de maniobra. Las Cortes de Madrid de 1551 pidieron la supresión de cofradías de un solo oficio para evitar acuerdos de autoprotección ${ }^{57}$; la Pragmática que ordenó disolver-

${ }^{56}$ B. QUETGLAS GAYÁ, Los gremios de Mallorca. Breve estudio histórico-sociológico de los Colegios Honorables Menestrales que florecieron en Mallorca desde el siglo XIII hasta el XIX, Palma de Mallorca, 1980, pp. 195-197.

57 "Otrosi, una de las causas principales que havido de las carestías de todas las cosas en estos reynos es que cada officio tiene confradias y ordenanças dellas, y algunas confirmadas por los del vuestro consejo, y otras de obispos y provissores, e que no pueden entrar en ellas sino officiales de officio, y estos se juntan muchas vezes en el año, y resulta de las dichas juntas poner precio a las cossas que han de vender, y esto veese claro porque no vende uno mas varato que otro, y si uno se encarga de una obra aunque la haga mal si el dueño se enoja con el no hay otro official que la tome, por que dize que va contra ordenança. Suplicamos a vuestra Magestad mande se desaagan las tales confradias aunque esten hechas con vuestra licencia ni de provissor: y de aqui adelante no se hagan, ni que los officiales hagan juntas, y que las justicias e regimientos de los pueblos provean veedores de los officios para que vean lo que esta bien hecho o 
las e imponía veedores de nombramiento municipal se publicó en 1552 y repercutió en diferentes pleitos que, como ya vimos, se resolvieron a favor de los plateros.

La inscripción en una corporación profesional era algo perfectamente normal en la organización del trabajo artístico e, incluso, era requisito indispensable para poder ejercer libremente la profesión y asumir contratos de trabajo. Pero no sólo en España, en los Países Bajos del Norte o en otros lugares en donde los artistas no habían conseguido la consideración de arte liberal para su actividad, sino también en la Italia del Quattrocento. Tenemos un ejemplo en Ghiberti, que trató de inscribirse en la Corporación de los plateros de Florencia y, al encontrarse con problemas para que fuera aceptado su ingreso, durante un tiempo, en 1426, estuvo matriculado en la de los escultores y arquitectos ${ }^{58}$.

Al mismo tiempo, los esfuerzos de los artistas por conseguir el reconocimiento de su actividad como arte liberal y diferenciada de los oficios, les llevó a rechazar esa consideración gremial y a buscar una denominación diferente para sus corporaciones. Pero eso no alteró la esencia de las instituciones tradicionales y la adscripción a alguna de ellas; ya fuera bajo el nombre de cofradía, gremio o Arte, continuó siendo lo más usual hasta que se generalizaron las instituciones académicas y sólo desapareció definitivamente a partir de la disolución de los gremios en las Cortes de Cádiz de 1813.

mal, e ansi no sera menester haver confradias" (Cortes de Madrid, Madrid, 1903, petición CXXX, p. 557).

58 Para poder inscribirse de forma rápida (¿para poder hacer las puertas del baptisterio?) había alegado una filiación "falsa" que fue descubierta. J. GARRIGA (ed.), Fuentes y documentos para la Historia del Arte. Renacimiento en Europa, Barcelona, 1983, doc. 5, pp. 82-85. En aquel tiempo, las 21 corporaciones profesionales de Florencia se dividían en 7 Arti Maggiori -referidas a grandes actividades productivas y mercantiles, como la seda, la lana y algunas profesiones liberales- y 14 Arti Menori -oficios artesanales en general-. Las diferencias sociales y económicas entre los miembros de las dos clases de artes eran muy considerables (S. R. SANTERBÁS, Op. cit., p. 57).
Cuando se publicó la Pragmática de supresión de las cofradías de un solo oficio, con el fin de evitar los acuerdos de autoprotección, los plateros de diferentes ciudades comen-zaron a alegar la ejecutoria que habían ganado sus compañeros de Plasencia, en relación a la prohibición de utilizar seda en los vestidos, y que había consagrado legalmente su pre-eminencia sobre los oficios mecánicos. La distinción entre oficio y artífice platero hizo que cada vez fuera más frecuente sustituir el término oficio, en relación con la actividad de los plateros, en favor de la expresión "arte de platero" 59 .

Los plateros madrileños eligieron la denominación "Arte de platería" para designar al conjunto de todos ellos, no solo la actividad, frente al término gremio ${ }^{60}$. Con ello no hacían sino poner de relieve la superioridad de la profesión frente a los oficios mecánicos o manuales.

En la Apología histórico-política de la antigüedad y nobleza del arte insigne y liberal de los plateros, impresa en 1700, haciendo gala de cierta falta de memoria, pero sin faltar totalmente a la verdad, se dice que nunca han tenido "nombre ni respeto de gremio, antes bien las leyes de Castilla siempre le han excluido de este significado" ${ }^{\prime \prime 1}$.

La estructura y organización de los talleres, con maestros, oficiales y aprendices no diferían de las de otros oficios artísticos. También eran similares los exámenes de pa-

\footnotetext{
${ }^{59}$ A. BARRÓN GARCÍA, La época dorada..., t. I, p. 75.

${ }^{60}$ J. M. CRUZ VALDOVINOS, Los plateros madrileños..., p. 228.

${ }^{61}$ Apología histórica-política de la antigüedad y noble$z a$ del arte insigne y liberal de los Plateros, con los establecimientos y ordenanzas esenciales para su puntual exercicio y observancia precisa de las leyes del Oro y de la Plata en todos los Reynos de España, que la Congregación del Glorioso Platero y Obispo San Eloy, compuesta de sus artífices, saca a la luz y humildemente consagra a los Reales Pies de N. Católico Monarca y Señor Don Carlos II (que Dios guarde), Madrid, 1700. Cfr. M. C. PESCADOR DEL HOYO, Op. cit., pp. $111-188$.
} 
santía, de los que conocemos cartas y libros de dibujos desde comienzos del siglo $\mathrm{XVI}^{62}$.

\section{CARGOS Y ACTIVIDADES DESEMPEÑADAS}

Uno de los puestos de mayor consi-deración para los artistas en general era el de responsable, en su especialidad, de la iglesia mayor. Al cargo de platero de la catedral accedieron los maestros más cualificados de las distintas diócesis. El nombramiento implicaba una tarea de carácter meramente artesanal, como era el mantenimiento y limpieza de los objetos de plata, a cambio de un salario, generalmente no muy alto $y$, en ocasiones, del disfrute de una casa perteneciente al cabildo. Una labor equivalente cumplían otros oficiales de la fábrica, como el borda-dor, el casullero, el librero o el pintor $^{63}$. Pero, al mismo tiempo, situaba al artífice en una posición ventajosa sobre los demás a la hora de labrar las piezas nuevas que la sede requiriese, le proporcionaba la clientela de parroquias que querían contar con obras similares a las del templo mayor, el contacto directo con maestros de otras artes y el prestigio social vinculado al cargo ${ }^{64}$.

Fuera del ámbito religioso, existió el cargo de platero del rey, que podía ser ocupado por varios plateros a un mismo tiempo. Entre los oficiales del rey Santo había tres arinteros de don Fernando, encargados de la plata, que formaban parte de la criazón del

${ }^{62}$ Sirva como ejemplo el caso de Valencia, en donde quedaron perfectamente regulados los exámenes en 1505 y se conservan dibujos realizados para la obtención de la maestría a partir de 1510. F. COTS MORATÓ, El examen de maestría en el arte de plateros de Valencia (1505-1882), Valencia, 2004.

${ }^{63}$ F. MARÍAS, "Maestros de la catedral, artistas y artesanos: datos sobre la pintura de la segunda mitad del siglo XVI. II", Archivo Español de Arte, 1983, pp. 1938.

${ }^{64}$ Una referencia la tenemos en el cabildo sevillano, que pagaba a Hernando de Ballesteros el Viejo, en 1556, 6.500 maravedís y a su hijo, por el mismo cargo, comenzó a pagarle 26.500 maravedís a partir de 1581. J. M. PALOMERO PÁRAMO, "La platería en la catedral de Sevilla", en La catedral de Sevilla, Sevilla, 1985, pp. 575-645, especialmente 578 . monarca $^{65}$. Los orebzes del rey Alfonso X, Simón, Giralt y Johan, obtuvieron posesiones en el repartimiento de Murcia. Simón debía gozar especialmente del favor real porque se le entregaron casas en esa ciudad y, además, poseía otras en el centro de Sevilla, muy cerca del Alcázar, al igual que Johan Pérez, "pintor del rey"66. Pedro el Ceremonioso une la expresión "familiar y doméstico nuestro" a la de "argenter de la Casa del Senyor Rei", lo que constituye una muestra del aprecio que sentía por sus plateros reales ${ }^{67}$. Los Reyes Católicos, Carlos I y Felipe II también tuvieron plateros a su servicio. Manuel Correa acompañó al aún príncipe Felipe en su viaje a Alemania (1548-1551), junto con otros artistas, y en la plica de su testamento cerrado, en 1573, se titula "platero de plata de su Magestad". Al morir, su salario por ese oficio era de 22.500 maravedís anuales, pero, además, el rey le había nombrado contraste de Corte y, en razón de ese cargo, tenía derecho a casa de aposento y salario de 15.000 maravedís al año ${ }^{68}$.

Otros cargos próximos a la Corte que desempeñaban los plateros eran los de marcador mayor del Reino y ensayador de la Casa de la Moneda, este último muy ambi-

${ }^{65}$ J. GONZÁLEZ, Reinado y diplomas de Fernando III, 3 vols., Córdoba, 1980/1983-1986, t. I, p. 123.

${ }^{66}$ Ibídem, vol. I, p. 313 y t. II, pp. 85-86 (R. CÓMEZ RAMOS, Las empresas artísticas de Alfonso X el Sabio, Sevilla, 1979, pp. 57-61).

${ }^{67}$ A. MOLINA Y CASTELLÁ, “L'argenter de la Casa del Senyor Rei: Una distinción laboral de prestigi", en J. YARZA y F. FITÉ (eds.), L'artista-artesá medieval a la Corona d'Aragó: actes, Lleida, 1999, pp. 365-383; N. de DALMASES Y BALAÑÁ, "Els argenters de la cort en temps de Pere III", en Pere el Ceremonios i la seva época, Barcelona, 1989, pp. 203-207.

${ }^{68}$ J. M. CRUZ VALDOVINOS, "Manuel Correa, platero de Felipe II", en El arte en las Cortes de Carlos I y Felipe II, Madrid, 1999, pp. 347-361. Tras la muerte del portugués Manuel Correa, en 1575, fue nombrado platero del rey el toledano Juan Rodríguez de Babia, que llegó a cobrar por dicho cargo 24.000 maravedís anuales (J. M. CRUZ VALDOVINOS, "Juan Rodríguez de Babia, platero de Felipe II", en Actas del Congreso Internacional Felipe II y las Artes, Madrid, 2000, pp. 657-672, especialmente, 660). 
cionado por su prestigio y retribución. Juan de Arfe consiguió de Felipe II el nombramiento y, al final de su vida, solicitó al rey que se lo otorgase a su yerno, Lesmes Fernández del Moral ${ }^{69}$.

En el ámbito municipal, los plateros ejercían el control sobre los metales y el mercado de la plata a través de los cargos de contraste y marcador. No era una ocupación menor, pues en algunos casos recibían por ella una remuneración sustanciosa. En una localidad de mediana relevancia, como Medina de Rioseco, aunque ciertamente con una actividad comercial importante, Pedro Núñez, nombrado contraste en 1520, cobraba 10.000 maravedís ${ }^{70}$.

Fuera del desempeño de su actividad profesional, algunos plateros consiguieron alcanzar otros puestos a los que no era fácil acceder desde la condición servil de artífice, si bien los ejemplos que conocemos nos sitúan ya a principios del siglo XVII, cuando José Velázquez Medrano llegó a ser alcalde ordinario de Pamplona y, entre 1614 y 1617, fue regidor de la ciudad ${ }^{71}$. Juan Álvarez de Peralta accedió al puesto de repostero de camas de Felipe IV quien, ante las quejas de sus colegas que se negaban a admitir entre ellos al platero, sentenció en 1657 que "el oficio de platero no es mecánico"72.

${ }^{69}$ A. BARRÓN GARCÍA, "Lesmes Fernández del Moral, platero y ensayador mayor", Boletín del Museo e Instituto Camón Aznar, no 59-60, 1995, pp. 5-36.

${ }^{70}$ Archivo Municipal de Medina de Rioseco, Registro de Diego de Barahona, Legajo 11, doc. 280 (Cfr. E. GARCÍA CHICO, Documentos para la Historia del Arte en Castilla. Plateros de los siglos XVI, XVII y XVIII, Valladolid, 1963, p. 9). J. C. BRASAS EGIDO, La platería vallisoletana y su difusión, Valladolid, 1980, p. 65.

${ }^{71}$ A de ORBE y M. C. HEREDIA, Biografía de los plateros navarros del siglo XVI. Aproximación a su entorno, Pamplona, 1998, p. 20.

${ }^{72}$ Juan Álvarez obtuvo el cargo como dote de su esposa, hija del capitán Valderrábano. El conde de Altamira, que salió en su defensa, argumentaba que "el ejercicio de platero no impide entrar en los honoríficos de la república". J. M. CRUZ VALDOVINOS, Los plateros madrileños..., pp. 231-232.
Por lo demás, su actividad habitual se desarrollaba en el taller, entre los encargos que recibía y las piezas que labraba para vender en la tienda. Sería muy interesante poder comparar la remuneración del trabajo de los plateros con la de los pintores o los escultores, pero resulta una tarea harto complicada debido a que depende de múltiples factores difíciles de cuantificar. Entre las circunstancias que habría que tener en cuenta están la capacitación de cada artífice y la demanda de obras que tiene; el lugar y el momento en que se encarga la obra y el promotor de la misma. Por ello, sólo cabría comparar los precios que se pagaban a artistas de similar consideración profesional, en un mismo marco geográfico y cronológico y por parte del mismo cliente. En el caso de las piezas de metales preciosos no es necesario considerar el valor de los materiales, pues siempre figura separadamente del de la hechura, pero existen otras variables como son el tipo de obra y la labor que esa obra lleve. Incluso, un mismo artista recibe cantidades diferentes por trabajos similares, como le ocurrió a Juan de Arfe con las diferentes custodias procesionales que labró. En la segunda mitad del siglo XVI, el precio medio de hechura por marco de plata era de 6 ducados; pero las obras normalmente no se contrataban a destajo, sino a tasación (aunque casi siempre se utilizaba un sistema mixto) y existían diferencias entre unos artífices y otros que pueden cifrarse entre los 3 y los 14 ducados por cada marco de hechura. Además, tampoco se valoraban igual las piezas lisas o las que llevaban figuras y relieves.

Una idea de la valoración, al menos económica, de las distintas artes podría obtenerse comparando los salarios de los artistas de la catedral. Por ejemplo, en Toledo, en 1576, Nicolás de Vergara cobraba como maestro de la catedral un salario de 24.000 maravedís anuales; el pintor Luis de Velasco, 7.000; el escultor, 8.000 y el vidriero, 30.000 maravedís ${ }^{73}$. No figura el salario del platero. Proba-

${ }^{73}$ F. MARÍAS, "Maestros de la catedral, artistas y artesanos: datos sobre la pintura de la segunda mitad 
blemente a nadie le extraña que el maestro de obras tuviera una remuneración más alta que el pintor y el escultor, pero sí sorprende, al menos desde nuestra mentalidad actual, que el vidriero poseyera el salario más alto de todos. En cualquier caso, hay que tener presente la posibilidad de que dependa de la empresa concreta en la que estuviera involucrada la catedral durante esos años. El problema se plantea también cuando vemos que no existe relación lógica entre los salarios pagados en una misma sede a dos maestros del mismo arte en fechas relativamente próximas y, por lo tanto, es prácticamente imposible llegar a conclusiones válidas de carácter global ${ }^{74}$.

En general, está claro que un maestro de platería con cierta reputación alcanzaría unos ingresos suficientes para tener un buen nivel de vida. Ello no impedía que quisiera acrecentar su poder adquisitivo con otras actividades de carácter mercantil o inmobiliario, de las que tenemos sobradas noticias y que concurrían, en numerosas ocasiones, en plateros con un importante volumen de encargos y reconocimiento profesional. Entre otros muchos, se puede citar a Hernando de Ballesteros el Viejo, que obtenía pingües beneficios con la compraventa de esclavos, $\mathrm{o}$ a su hijo, Hernando de Ballesteros el Mozo, que se denomina a sí mismo "mercader de oro y plata"75. Más frecuente era el arrendamiento de tierras, viñas y casas propias $u$ obtenidas en censo de por vida. En esto también los plateros coinciden con otros artífices de posición económica desahogada. Cuando el convento de San Benito de Valladolid dio terrenos a Alonso Berruguete para edificar sus casas principales, le exigió que no abrie-

del siglo XVI. I", Archivo Español de Arte, 1981, pp. 319340, especialmente 320.

${ }^{74}$ Ya he citado el ejemplo del cabildo sevillano, que pagaba a Hernando de Ballesteros el Viejo, en 1556, 6.500 maravedís y a su hijo, por el mismo cargo, comenzó a pagarle 26.500 maravedís a partir de 1581 (J. M. PALOMERO PÁRAMO, Op.cit., especialmente p. 581).

${ }^{75}$ A. J. SANTOS MÁRQUEZ, Los Ballesteros. Una familia de plateros en la Sevilla del Quinientos, Sevilla, 2007. ra taberna ni tuviera en ellas más vino que el del propio consumo, lo que significa que la venta de etílico constituía un saneado ingreso y el monasterio temía que Berruguete pudiera establecer competencia ${ }^{76}$.

Estar al servicio del rey, de la catedral o tener cargos administrativos era un factor de consideración social. También lo era preciarse de hidalguía y se utilizó como una de las razones para la defensa de la nobleza de las artes. No fueron muchos los artistas que la poseyeron. Alonso Berruguete, antes aludido, constituye casi una excepción: miembro de la clase media urbana de los caballeros, aunaba cargo institucional y un pequeño señorío de villa o aldea $y$, además, ejercía de pintor y escultor; fundó un mayorazgo, era escribano del crimen y, según Palomino, Carlos I le honró con el oficio de ayuda de cámara. También Juan de Herrera, Sánchez Coello o el escultor burgalés Bartolomé Ordóñez figuraban entre los hidalgos ${ }^{77}$.

En el campo de la platería se encontraba entre este grupo privilegiado un porcentaje similar. En el rico ajuar de Hernando de Oñate el Mayor se incluía un repostero con el blasón familiar; Luis de Suescun utilizó el león heráldico de su apellido en el troquel personal de platero ${ }^{78}$; Cristóbal de Vergara, autor de la custodia de Medina del Campo, expresó en sus mandas testamentarias el deseo de ser enterrado en el monasterio de San Francisco de esa localidad, en una de las cuatro tumbas que tenía "junto a un pilar que tiene una piedra con mis armas"79.

Probablemente, el caso más notable, por conocido, es el de los Arfe. Antonio estuvo preso tres años hasta concluir el proceso de probanza de hidalguía, condición que le exi-

${ }^{76}$ J. J. MARTÍN GONZÁLEZ, Op. cit., especialmente 435 .

${ }^{77}$ F. CHECA CREMADES, Felipe II..., Madrid, 1992, p. 247.

\footnotetext{
${ }^{78}$ A. de ORBE y M. C. HEREDIA, Op. cit., p. 20.

${ }^{79}$ E. GARCÍA CHICO, Op. cit., pp. 16-18.
} 
mía de la pena de cárcel por deudas ${ }^{80}$. Cuando su hijo Juan fue encarcelado por razones similares, solamente tardó dos meses en presentar dicha probanza y, en el proceso, los testigos aludieron a las cartas de nobleza que poseía su abuelo, Enrique de Arfe, y a las actividades que compartía con la cofradía de caballeros y escuderos de León ${ }^{81}$.

\section{A MODO DE REFLEXIÓN FINAL}

Después de terminar la custodia de Sevilla y la Varia commensvración, las dos obras más señeras de la platería hispana desde el punto de vista práctico y teórico, respectivamente, y en las que se puso de manifiesto con mayor claridad la nobleza y liberalidad del arte de la platería, Juan de Arfe se ofreció a hacer una custodia procesional para la catedral de Burgos. Cinco años más tarde, en 1593, se desencadenó el pleito por llevar el pendón en la procesión del Corpus y da la impresión de que Arfe despreciaba la platería y se sentía más importante denominándose arquitecto y escultor ${ }^{82}$.

La explicación debe ser otra. Hay numerosas razones que indican que Juan de Arfe no creía que el arte de la platería estuviera por debajo de la escultura, además de la defensa que acababa de hacer en la Varia

${ }^{80}$ Varias veces hicieron ostentación Antonio y su hijo Juan de esa hidalguía, de la que, sin embargo, no hizo nunca mención Enrique. M. V. HERRÁEZ ORTEGA, "La familia de los Arfe", en Centenario de la muerte de Juan de Arfe, Sevilla, 2004, pp. 15-42, especialmente, p. 37; M. C. HEREDIA MORENO, "Juan de Arfe y Villafañe, entre la hidalguía y la picaresca. Problemática sobre una situación financiera", en J. RIVAS CARMONA (coord.), Estudios de platería. San Eloy 2004, Murcia, 2004, pp. 197-210, especialmente 200.

${ }^{81}$ N. ALONSO CORTÉS, "Noticias de los Arfe", Boletín de la Real Academia de la Historia, 1951, pp. 71-98.

${ }^{82}$ Entre las publicaciones que aportan un mayor número de datos sobre la estancia de Juan de Arfe en Burgos y sobre el pleito mantenido con la cofradía de San Eloy de esa ciudad cabe destacar J. MARTÍ MONSÓ, Op. cit.; J M. CRUZ VALDOVINOS, "El platero Juan de Arfe", especialmente pp. 10-12; A. BARRÓN GARCÍA “Juan de Arfe en Burgos", pp. 249-278; M. C. HEREDIA MORENO, "Juan de Arfe y Villafañe, entre la hidalguía y la picaresca...", pp. 197-210. commensvración. Antes del pleito siempre se había denominado platero, incluso en los escritos dirigidos al cabildo de Burgos; sólo en el documento de tasación de los cetros que Alonso González hizo para Torquemada, en 1589, aparece como escultor de oro y plata. También se llama escultor cuando contrata los ciriales para el convento del Carmen de Valladolid, pero estamos hablando del año 1595 y es probable que en ese momento lo haga de forma ostentosa porque aún no se ha resuelto el pleito. Había recibido trato y honores similares a los de los grandes artífices de la pintura o la escultura de su tiempo. Mantenía relación con escultores como Esteban Jordán, un artista de elevada posición económica y social, que poseía altar propio en la parroquia de San Ildefonso de Valladolid, que en su instrucción de mayorazgo dejó ordenado que tanto su hija como los que la sucediesen debían contraer matrimonio con gente que no tuviese oficios "bajos y mecáni$\cos ^{\prime \prime}$ y que, sin embargo, afirma tener amistad con Arfe desde hacía treinta años y firmó, en su nombre, el contrato de la custodia del Carmen de Valladolid ${ }^{83}$. Por estas fechas, hay artistas en los círculos en los que él se mueve que practican las dos artes, sin menosprecio de ninguna de ellas; por ejemplo, en Burgos tiene abierto su taller Jerónimo Corseto, escultor y platero a un mismo tiempo $^{84}$, y en la Corte está trabajando Jacopo da Trezzo, a cuya interdisciplinariedad ya he hecho alusión anteriormente. Un indicio más de la valoración y aprecio que Arfe siente por la platería y sus artífices es el hecho de que en 1592 su única hija, Germana, contrajera matrimonio con un platero.

¿A qué responde entonces su actitud? Frente al Parnaso sevillano en donde el platero se había convertido en un verdadero humanista, a finales del siglo XVI Burgos era una ciudad relativamente provinciana. Juan de Arfe no tenía intención de residir mucho

\footnotetext{
${ }^{83} \mathrm{~N}$. ALONSO CORTÉS, Op. cit.

${ }^{84}$ A. BARRÓN GARCÍA, “Jerónimo Corseto y Pedro García Montero, plateros", Boletín del Seminario de Arte y Arqueología, Valladolid, t. LXII, 1996, pp. 359-377.
} 
tiempo allí; pretendía continuar avecindado en Valladolid, en donde también estaba construyendo la custodia grande de la iglesia mayor y en donde esperaba la llamada del rey para pasar a su servicio. Pero el cabildo burgalés le impuso establecer un taller en la ciudad, en donde labrase la obra y del que las piezas que fuera terminando no saliesen sino para ser guardadas a buen recaudo por el canónigo fabriquero.

También le impuso que compartiera el trabajo con artífices de la localidad. Pero Juan no tenía intención de convivir, ni menos de compartir tareas y, conse-cuentemente, beneficios, con los plateros burgaleses. Colaboraron con él algunos de los oficiales que estaban a su servicio y, debido a la insistencia del cabildo, finalmente prometió dar a labrar cuarenta marcos de plata a Nicolás de Alvear, que ostentaba desde hacía años el cargo de platero de la catedral.

Su posición social y su reconocimiento profesional estaban por estos años en el cénit de su carrera. Recibía multitud de encargos por parte de la Iglesia, del rey y de la nobleza, cobraba los precios más altos que se conocen (bien es cierto que los capitulares de Burgos iban a pagarle menos que los de Sevilla y que los de Valladolid) y era solicitado como tasador por plateros de las provincias vecinas, probablemente porque sus valoraciones eran altas en señal del aprecio que sentía por este arte y del nivel al que quería colocarlo.

Sin embargo, su relación con los plateros burgaleses no era buena. Por un lado, no quiso inscribirse en el gremio. Podría parecer un testimonio de su concepción liberal de la actividad artística, pero hemos visto que era prácticamente obligado para todos los artífices y lo cierto es que él era cofrade de Nuestra Señora del Val y San Eloy de Valladolid, en donde había ocupado los dos cargos principales: mayordomo (1567) y alcalde (1570). Por lo tanto, su negativa puede interpretarse como un desprecio, exclusivamente, hacia los plateros de Burgos. Por otro lado, la presencia de Arfe en la ciudad significaba una fuerte competencia para los obradores burgaleses y, encima, no quería compartir trabajo con ellos.

En ese contexto, la invitación a participar en la procesión del Corpus, como portador del pendón, más que un honor puede interpretarse como una imposición. Cuando Arfe alegaba que no tenía obligación de portar el pendón, porque no era vecino de la ciudad ni cofrade de San Eloy, los plateros de Burgos replicaban que llevaba tres años viviendo allí y que tenía casa y tienda, es decir, estaban aludiendo a su obligación de inscribirse en la cofradía. Era una manera de forzarle a formar parte del grupo profesional en el que se resistía a entrar, posiblemente porque quería mantener su libertad personal y de oficio, además de impedir cualquier tipo de control sobre los asuntos financieros que traía entre manos. Y la única manera que tenía de zafarse era afirmar que no pertenecía a ese colectivo sino al de los escultores y arquitectos. Tal vez, incluso, era una forma de invitarle a irse por el daño que suponía para la actividad de los artífices burgaleses la fuerte competencia del taller de Arfe y de la sociedad que formó con su yerno, el platero burgalés Lesmes Fernández del Moral, desde $1592^{85}$.

En realidad, los escritos de Juan de Arfe en defensa del arte de la platería respondían a una opinión que, progresivamente, se generalizó entre los plateros de la segunda mitad del siglo XVI, si bien la mayoría de ellos debía ser ajena a la polémica que se desarrollaba en el Cinquecento italiano sobre la primacía de las artes. Vivían en un nivel social similar al de otros artistas y con un reconocimiento legal que los situaba por encima de los oficios menestrales. De hecho, la respuesta que dan a Juan de Arfe, dentro de su aparente ingenuidad, se vale de los argumentos utilizados por el propio teórico en el prólogo de la Varia para demostrar la liberalidad de su arte: cualquier buen platero es escultor de oro y plata.

${ }^{85}$ A. BARRÓN GARCÍA, "Lesmes Fernández del Moral...", pp. 5-36. 